\title{
Sifat Fisis dan Mekanis Papan Partikel Limbah Kulit Buah Kakao Berpenguat Batang Kayu Jabon
}

Tiwuk Wulandaria ${ }^{a}$ Asifa Asria* ${ }^{*}$ Irfana Diah Faryuni ${ }^{\mathrm{a}}$

\author{
aProgram Studi Fisika, Jurusan Fisika, FMIPA Universitas Tanjungpura \\ Jalan Prof. Dr. Hadari Nawawi, Pontianak, Indonesia \\ *Email: asifa.asri@physics.untan.ac.id
}

\begin{abstract}
Abstrak
Penelitian ini memanfaatkan limbah kulit buah kakao sebagai bahan baku pembuatan papan partikel. Untuk memperbaiki sifat fisis dan mekanis dari papan partikel ini, ditambahkan batang kayu jabon yang berperan sebagai penguat. Pabrikasi papan partikel berukuran $30 \mathrm{~cm}$ x $30 \mathrm{~cm}$ x $1 \mathrm{~cm}$ diawali dengan pencampuran bahan baku, urea formaldehyde (UF), parafin, dan katalis. Kemudian bahan-bahan tersebut di kempa dengan tekanan $30 \mathrm{~N} / \mathrm{cm}^{2}$ pada suhu $150^{\circ} \mathrm{C}$ selama 8 menit. Dilakukan 7 variasi komposisi massa antara kulit buah kakao dan batang kayu jabon secara berturut-turut adalah 100:0, 90:10, 80:20, 70:30, 60:40, 50:50, dan 0:100. Papan partikel diuji melalui uji fisis yaitu kerapatan, kadar air, pengembangan tebal dan uji mekanis yaitu modulus of elasticity (MOE), modulus of rupture (MOR), internal bond (IB), kuat pegang sekrup. Hasil pengujian papan partikel mengacu pada standar JIS A 5908:2003. Berdasarkan hasil yang diperoleh, nilai kerapatan sudah memenuhi standar dengan interval nilai $0,760 \mathrm{~g} / \mathrm{cm}^{3}$ sampai $0,855 \mathrm{~g} / \mathrm{cm}^{3}$. Setelah penambahan batang kayu jabon, sifat fisis dan mekanis mengalami peningkatan kualitas dibandingkan dengan papan partikel tanpa batang kayu jabon. Nilai kadar air dan pengembangan tebal menurun seiring dengan penambahan penguat. Begitu juga dengan nilai MOE, MOR, IB, dan kuat pegang sekrup semakin meningkat saat kuantitas penguat semakin banyak.
\end{abstract}

Kata Kunci : batang kayu jabon, kulit buah kakao, papan partikel, dan penguat.

\section{Latar Belakang}

Hasil pengolahan kakao dari lahan perkebunan menghasilkan limbah berupa kulit buah kakao, kayu kakao, dan daun kakao. Selama ini, kulit buah kakao hanya digunakan sebagai pembuatan gula cair dan pakan ternak tanpa ada pemanfaatan lebih lanjut [1]. Hasil ikutan yang proporsinya paling besar dihasilkan yaitu kulit buah kakao. Produksi satu ton biji kakao kering menghasilkan sekitar 10 ton kulit buah kakao segar [2]. Berdasarkan data Statistik Perkebunan Indonesia pada tahun 2015 luas perkebunan buah kakao sebesar 1.709.284 ha dengan produksi biji kakao sebesar 593.331 ton. Perkebunan buah kakao di Kalimantan Barat pada tahun 2015 adalah 11.535 ha dengan jumlah produksi biji kakao sebesar 1.845 ton [3]. Artinya pada tahun 2015 limbah kulit buah kakao hasil produksi mencapai 18.450 ton. Pemanfaatan limbah kulit buah kakao diharapkan mampu mengurangi jumlah sampah dan memanfaatkannya menjadi barang yang dapat digunakan atau dijual seperti papan partikel. Limbah kulit buah kakao mengandung lignoselulosa yang dapat digunakan sebagai bahan baku papan partikel [4]. Namun, kulit buah kakao memiliki kandungan lignoselulosa yang sedikit sehingga perlu penambahan suatu bahan untuk memperkuatnya.

Pohon Jabon (Anthocephalus cadamba Miq) merupakan jenis tanaman yang berkualitas dan memiliki umur masak tebang yang relatif cepat (fast growing species) [5]. Kandungan lignoselulosa yang terdapat pada kayu jabon sangat potensial jika digunakan untuk papan partikel. Sehingga dalam penelitian ini limbah kulit buah kakao akan dimanfaatkan menjadi papan partikel dengan batang jabon sebagai penguatnya dan resin sebagai bahan pengikat.

Menurut Khaerudini [6], mengenai komposit sludge-serbuk kayu sebagai penguat terhadap sifat mekanis material komposit yang menggunakan variasi komposisi sludge-serbuk kayu yaitu 60:40, 70:30, 80:20 dan variasi urea formaldehida (UF) 8\%,10\%, dan 12\%, diperoleh bahwa komposit dari serbuk kayu dengan komposisi 60:40 dan perekat 12\% merupakan sampel dengan komposisi terbaik dalam hal sifat mekanisnya. Semakin tinggi kadar perekat yang digunakan maka semakin baik pula sifat fisis dan mekanis papan partikel. Untuk itu pada penelitian ini komposisi antara limbah kulit buah kakao dan batang jabon yang digunakan adalah 100\% kulit buah kakao, 90:10, 80:20, $70: 30,60: 40,50: 50$, dan $100 \%$ batang jabon dengan UF yang digunakan $12 \%$.

\section{Metodologi}

\section{Material dan peralatan}

Bahan yang digunakan adalah kulit buah kakao, kayu jabon, akuades, katalis (Amonium Klorida), $\mathrm{NaOH}$, parafin, dan urea formaldehyde (UF). Peralatan yang digunakan dalam penelitian ini adalah alat press hidrolik panas 
(Hotpress), ayakan $2.0 \mathrm{~mm}$, bak plastik, batang pengaduk, cetakan, desikator, gelas kimia, gergaji, jangka sorong, lempeng aluminium, oven, pemotong (Hammer mill), plat besi, timbangan digital, dan Universal Testing Machine (alat uji sifat mekanis).

\section{Persiapan bahan baku}

Kulit buah kakao dipotong dengan panjang $5 \mathrm{~cm}$, lalu direndam dalam larutan $\mathrm{NaOH}$ 5\% selama 2 jam. Kulit buah kakao dibilas dengan akuades hingga bersih lalu dijemur di bawah sinar matahari sampai kering. Sampel kulit buah kakao yang telah kering, kemudian digiling dengan hammer mill. Kayu Jabon dipotong menggunakan gergaji dengan ukuran panjang $60 \mathrm{~cm}$. Kemudian kayu jabon di hancurkan dengan hammer mill dan dijemur sampai benar-benar kering. Bahan yang telah digiling dipisahkan berdasarkan ukuran butir dengan menggunakan ayakan berukuran 2.0 $\mathrm{mm}$. Bahan tersebut dikeringkan di dalam oven dengan suhu $60-80^{\circ} \mathrm{C}$ hingga mencapai target kadar air (KA) 5\% [7].

\section{Pembuatan papan partikel}

Serbuk dimasukkan ke dalam bak dan dicampur dengan campuran perekat, lalu diaduk secara manual sampai perekat dan serbuk tercampur secara merata. Cetakan disiapkan dengan ukuran $30 \mathrm{~cm}$ x $30 \mathrm{~cm} \times 1 \mathrm{~cm}$, kemudian adonan dimasukkan ke dalam cetakan dan disusun secara teratur agar ketebalannya merata. Cetakan ditutup dan ditekan secara manual hingga penutup cetakan menekan bahan secara merata. Setelah dicetak, bahan dimasukkan ke dalam hot press yang sebelumnya telah dipanaskan selama 15 menit dengan tekanan $30 \mathrm{~N} / \mathrm{cm}^{2}$ pada suhu $150^{\circ} \mathrm{C}$ selama 8 menit [8]. Papan partikel yang sudah jadi kemudian ditempatkan pada suhu ruangan selama 7 hari.

\section{Pemotongan Contoh Uji}

Standar yang digunakan untuk pembuatan contoh uji sesuai dengan standar JIS A 5908:2003 [9].

\section{Pengujian Sifat Fisis Papan Partikel a. Kerapatan}

Kerapatan dengan contoh uji $10 \mathrm{~cm} \times 10$ $\mathrm{cm}$ ditimbang untuk mengetahui massa sampel. Kemudian dilakukan pengukuran dimensi yang meliputi panjang, lebar, dan tebal untuk mengetahui volume contoh uji. Persamaan untuk mencari kerapatan yaitu [7]:

$$
\rho=\frac{m}{V} \text {. }
$$

$$
\begin{aligned}
& \rho=\operatorname{Kerapatan}\left(\mathrm{g} / \mathrm{cm}^{3}\right) \\
& m=\text { Massa contoh uji }(\mathrm{g}) \\
& V=\text { Volume contoh uji }\left(\mathrm{cm}^{3}\right)
\end{aligned}
$$

\section{b. Kadar Air}

Contoh uji berukuran $10 \mathrm{~cm}$ x $10 \mathrm{~cm}$ ditimbang massa awalnya. Sampel tersebut di keringkan dalam oven pada suhu $103 \pm 2{ }^{\circ} \mathrm{C}$ selama 24 jam. Kemudian contoh uji dimasukkan ke dalam desikator selama 10 menit dan selanjutnya ditimbang. Hal ini dilakukan sampai mencapai berat konstan yaitu massa kering oven. Kadar air dapat dihitung dengan menggunakan persamaan [7]:

$$
\mathrm{KA}=\frac{M K A-M K O}{M K O} \times 100 \%
$$

Keterangan:

$\mathrm{KA}=$ Kadar Air (\%)

MKA = Massa Kering Awal (g)

$\mathrm{MKO}=$ Massa Kering Oven (g)

\section{c. Pengembangan Tebal}

Pengembangan tebal dengan ukuran contoh uji $5 \mathrm{~cm}$ x $5 \mathrm{~cm}$ diukur tebal sisi-sisinya dan hasilnya dirata-ratakan. Contoh uji direndam dengan air dingin selama 24 jam kemudian dilakukan pengukuran kembali. Pengembangan tebal dihitung dengan menggunakan persamaan [7]:

$$
\mathrm{TS}=\frac{\mathrm{T} 2-\mathrm{T} 1}{\mathrm{~T} 1} \times 100 \% \text {. }
$$

Keterangan:

TS = Pengembangan Tebal $(\%)$

$\mathrm{T}_{1}=$ Tebal sebelum perendaman $(\mathrm{cm})$

$\mathrm{T}_{2}=$ Tebal setelah perendaman $(\mathrm{cm})$

\section{Pengujian Sifat Mekanis Papan Partikel a. MOE}

Keteguhan lentur atau MOE contoh ujinya berukuran $5 \mathrm{~cm}$ x $20 \mathrm{~cm}$ diukur lebar dan tebalnya. Kemudian contoh uji dibentangkan pada mesin Universal Testing Machine dengan jarak sanggah $15 \mathrm{~cm}$. Beban diberikan di tengahtengah jarak sanggah dan dilakukan sampai batas titik elastik contoh uji. MOE dapat dihitung dengan persamaan [7]:

$$
\mathrm{MOE}=\frac{\Delta \mathrm{PL}^{3}}{4 \Delta \mathrm{Ybh}^{3}}
$$

Keterangan:

$$
\begin{array}{ll}
\mathrm{MOE} & =\text { Keteguhan lentur }\left(\mathrm{kg} / \mathrm{cm}^{2}\right) \\
\Delta \mathrm{P} & =\text { Perubahan beban }(\mathrm{kg}) \\
\mathrm{L} & =\text { Jarak sangga }(\mathrm{cm}) \\
\Delta \mathrm{Y} & =\text { Perubahan defleksi }(\mathrm{cm}) \\
\mathrm{b} & =\text { Lebar contoh uji }(\mathrm{cm}) \\
\mathrm{h} & =\text { Tebal contoh uji }(\mathrm{cm})
\end{array}
$$




\section{b. MOR}

Pengujian keteguhan patah atau MOR dilakukan bersamaan dengan pengujian keteguhan lentur (MOE) dengan memakai contoh uji yang sama. Tetapi pada MOR pengujiannya dilakukan sampai contoh uji mengalami patah. Keteguhan patah dihitung dengan menggunakan persamaan [7]:

$$
\mathrm{MOR}=\frac{3 \mathrm{PL}}{2 \mathrm{bh}^{2}} .
$$

Keterangan:

$$
\begin{array}{ll}
\text { MOR } & =\text { Keteguhan patah }\left(\mathrm{kg} / \mathrm{cm}^{2}\right) \\
\mathrm{P} & =\text { Beban maksimum }(\mathrm{kg}) \\
\mathrm{L} & =\text { Jarak sangga }(\mathrm{cm}) \\
\mathrm{b} & =\text { Lebar contoh uji }(\mathrm{cm}) \\
\mathrm{h} & =\text { Tebal contoh uji }(\mathrm{cm})
\end{array}
$$

\section{c. Keteguhan Rekat Internal}

Contoh uji berukuran $5 \mathrm{~cm} \times 5 \mathrm{~cm}$ diukur panjang dan lebarnya untuk menghitung luas permukaan. Kemudian dua buah balok baja yang berukuran $5 \mathrm{~cm}$ x $5 \mathrm{~cm}$ direkatkan di contoh uji dengan menggunakan perekat epoxy dan dibiarkan sampai mengering. Contoh uji diletakkan pada mesin uji dan balok baja ditarik tegak lurus permukaan contoh uji sampai diketahui nilai beban maksimumnya. Keteguhan rekat internal dapat dihitung menggunakan persamaan [7]:

$$
\mathrm{IB}=\frac{\mathrm{P}}{\mathrm{A}} .
$$

Keterangan:

IB = Internal Bond $\left(\mathrm{kg} / \mathrm{cm}^{2}\right)$

$\mathrm{P}=$ Beban Maksimum $(\mathrm{kg})$

$A$ = Luas Penampang $\left(\mathrm{cm}^{2}\right)$

\section{d. Kuat Pegang Sekrup}

Ukuran contoh uji $5 \mathrm{~cm}$ x $10 \mathrm{~cm}$ dimasukkan sekrup yang berdiameter $2,7 \mathrm{~mm}$ dan panjang $16 \mathrm{~mm}$ hingga mencapai kedalaman $8 \mathrm{~mm}$. Contoh uji diapit pada sisi kanan dan kiri, kemudian ditarik hingga beban maksimum sampai sekrup tercabut. Besarnya beban maksimum kuat pegang sekrup dinyatakan dalam satuan kilogram (kg).

\section{Hasil dan Pembahasan}

\section{Hasil Pabrikasi Papan Partikel}

Papan partikel dengan variasi komposisi penguat batang kayu jabon tersaji pada Gambar 1. Secara visual terlihat bahwa terdapat perubahan warna dari coklat tua ke coklat yang lebih muda setelah komposisi penguat ditambahkan. Hal ini dikarenakan batang kayu jabon sebagai penguatnya mempunyai warna yang putih kekuningan [10]. Jika semakin banyak komposisi partikel batang kayu jabon yang ditambahkan maka warna papan partikel yang dihasilkan berubah ke coklat muda.

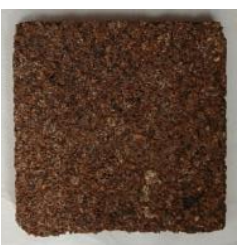

(a)

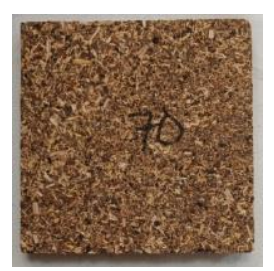

(d)

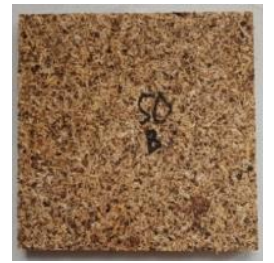

(f)

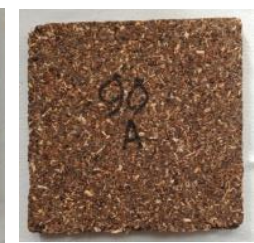

(b)

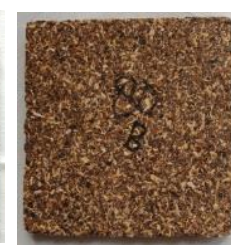

(c)

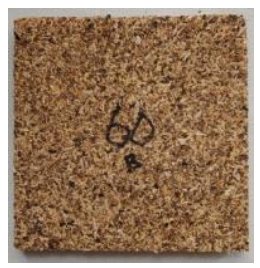

(e)

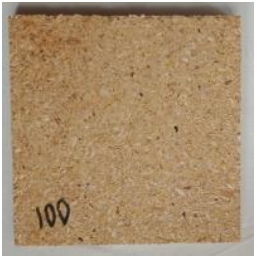

(g)

Gambar 1 Papan partikel hasil pabrikasi $30 \mathrm{~cm} \mathrm{x}$ $30 \mathrm{~cm}$ dengan komposisi kulit buah kakao dan batang kayu jabon berturut-turut; (a) 100:0; (b) 90:10; (c) 80:20; (d) 70:30; (e) 60:40; (f) 50:50; dan (g) 0:100.

\section{Sifat Fisis Papan Partikel a. Kerapatan}

Kerapatan adalah perbandingan antara massa dan volume suatu benda. Pada penelitian ini, nilai kerapatan terendah terdapat pada papan partikel dengan komposisi $100 \%$ batang kayu jabon. Nilai kerapatan tertinggi terdapat pada sampel yang dibuat dari 100\% kulit buah kakao. Hal tersebut dikarenakan partikel kulit buah kakao memiliki massa jenis yang besar, dibandingkan batang kayu jabon. Semakin tinggi massa jenis suatu benda, berarti semakin besar massa setiap volumenya. Secara keseluruhan nilai kerapatan papan partikel yang dihasilkan sudah memenuhi standar JIS A 5908:2003 yaitu $0,4-0,9\left(\mathrm{~g} / \mathrm{cm}^{3}\right)$. Nilai kerapatan papan partikel pada penelitian ini dapat dilihat pada gambar 2 .

Papan partikel yang dibuat sudah ditargetkan bahwa akan memiliki kerapatan sekitar $0,7 \mathrm{~g} / \mathrm{cm}^{3}$. Hasil nilai kerapatan papan partikel yang ditunjukkan pada Gambar 2 terlihat bahwa papan partikel yang dibuat sesuai dengan target yang diharapkan yaitu $0,760 \mathrm{~g} / \mathrm{cm}^{3}-0,855 \mathrm{~g} / \mathrm{cm}^{3}$. 


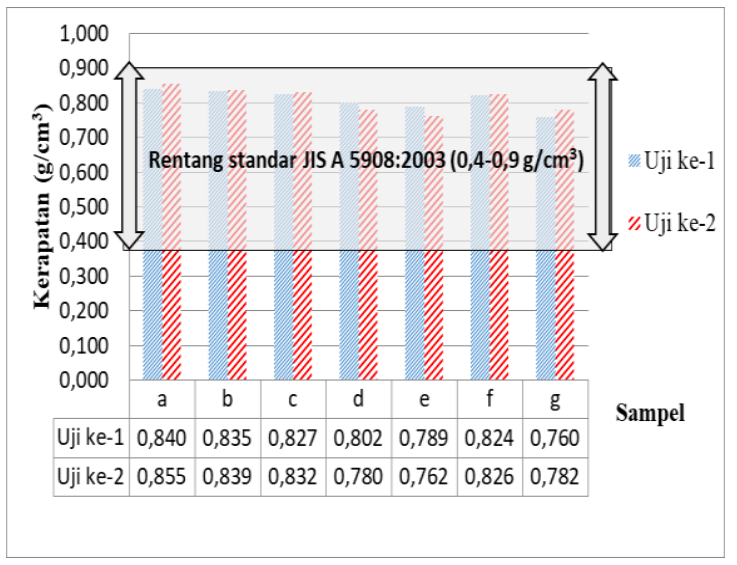

Gambar 2 Nilai kerapatan papan partikel pada setiap sampel untuk uji pertama dan uji kedua.

\section{b. Kadar Air}

Penelitian ini nilai tertinggi yaitu pada sampel $a(100 \%$ kulit buah kakao). Kemudian nilai terendah terdapat pada sampel $g(100 \%$ batang kayu jabon). Hasil pengujian kadar air dapat dilihat pada Gambar 3.

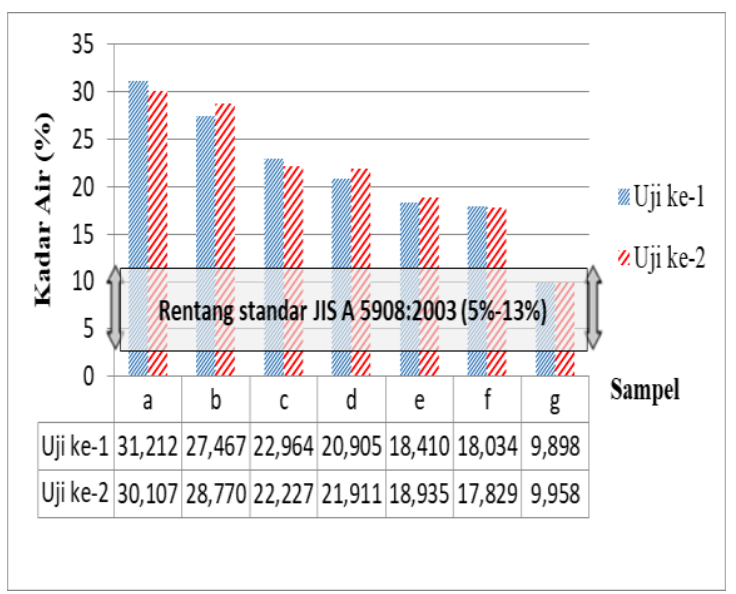

Gambar 3 Nilai kadar air papan partikel pada setiap sampel untuk uji pertama dan uji kedua.

Hal ini diduga karena semakin banyak kandungan batang kayu jabon di dalam papan pertikel, rongga yang terbentuk semakin berkurang sehingga air semakin sulit untuk menempati papan partikel. Berkurangnya rongga tersebut diakibatkan karena massa jenis partikel batang kayu jabon lebih kecil dibandingkan partikel kulit buah kakao (sekitar tiga kali lebih kecil). Sehingga, saat komposisi partikel kayu jabon ditambahkan, jumlah partikel bahan baku penyusun papan partikel menjadi semakin padat dan rongga menjadi semakin berkurang. Perubahan rongga-rongga yang terbentuk pada setiap sampel secara kualitatif disajikan pada Gambar 4.

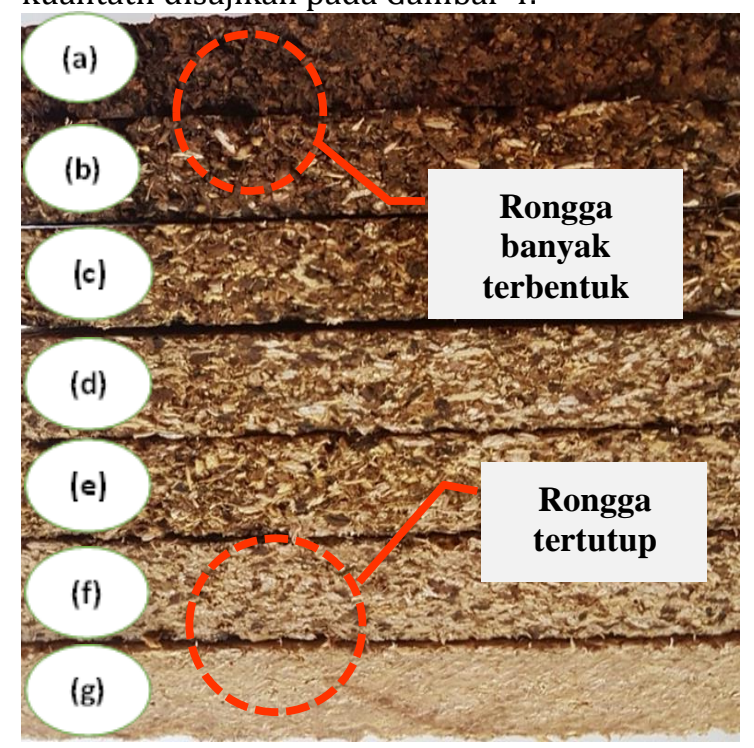

Gambar 4 Papan partikel tampak samping untuk setiap sampel dengan komposisi kulit buah kakao dan batang kayu jabon berturut-turut; (a) 100:0; (b) 90:10; (c) $80: 20 ;$ (d) 70:30; (e) 60:40; (f) 50:50; dan (g) 0:100.

Nilai kadar air yang tinggi dikarenakan tidak meratanya distribusi perekat. Pencampuran bahan yang tidak merata, akan menyebabkan banyaknya spots pada papan partikel. Sehingga mengakibatkan bagian lain kekurangan perekat.

\section{c. Pengembangan Tebal}

Pengembangan tebal dilakukan dengan mengamati perubahan dimensi papan partikel setelah direndam selama 24 jam. Kualitas papan partikel akan semakin baik jika pengembangan tebalnya semakin kecil. Penelitian ini hanya satu sampel yang memenuhi standar yakni sampel $g$. Pada nilai pengembangan tebal papan partikel dengan batang kayu jabon sebagai penguat $b, c$, $d, e$, dan $f$ belum memenuhi standar JIS, namun sifatnya mengalami perubahan kekualitas yang lebih baik. Hasil pengujian pengembangan tebal papan partikel dapat dilihat pada Gambar 5.

Nilai pengembangan tebal sebanding dengan nilai kadar air pada hasil grafik batang di Gambar 3. Nilai kadar air yang rendah mengakibatkan daya serap air pada papan partikel menjadi kecil sehingga pengembangan tebal juga akan semakin menurun. Penyebab semakin rendahnya nilai pengembangan tebal saat partikel batang kayu jabon ditambahkan, sama dengan penjelasan pada sub bab kadar air mengenai rongga yang semakin mengecil. Semakin padat struktur papan partikel, maka tingkat absorbsi air oleh papan partikel akan 
menurun sehingga nilai pengembangan tebal semakin kecil.

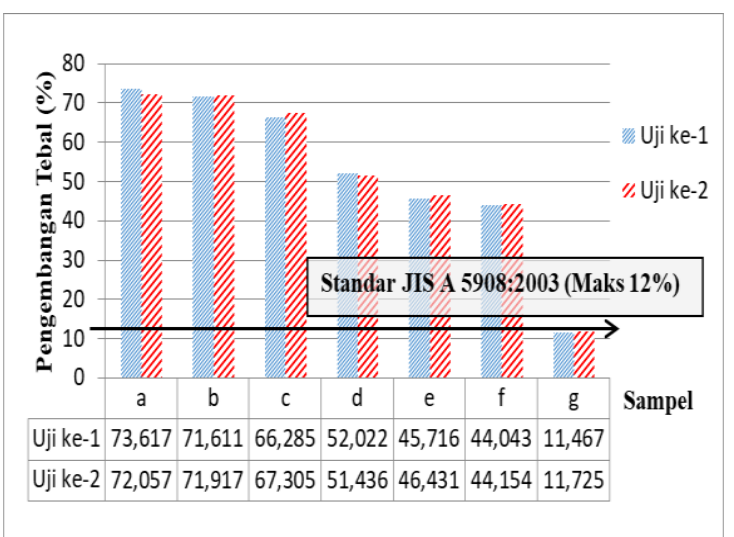

Gambar 5 Nilai pengembangan tebal papan partikel pada setiap sampel untuk uji pertama dan uji kedua.

Tingginya pengembangan tebal papan partikel dapat disebabkan oleh tingkat absorbsi air oleh bahan baku dan sifat perekat yang digunakan. Hal ini terjadi karena pada saat proses pengempaan panas, partikel dipadatkan yang mengakibatkan rongga partikel akan mengecil. Saat perendaman rongga partikel akan kembali ke dimensi semula akibat dari penyerapan air [11].

\section{Sifat Mekanis Papan Partikel a. MOE}

Modulus of Elasticity (MOE) atau keteguhan lentur merupakan ukuran ketahanan papan untuk mempertahankan bentuk yang berhubungan dengan kekakuan papan partikel. Sifat kekakuan tersebut merupakan ukuran kemampuan suatu benda untuk menahan suatu perubahan bentuk atau lenturan. Hal tersebut terjadi akibat pembebanan dan hanya berlaku sampai batas proporsi [12].

Semakin tinggi nilai MOE papan partikel maka semakin tahan terhadap perubahan bentuk. Sehingga, kemampuan dalam menahan beban semakin besar. MOE papan partikel tertinggi terdapat pada sampel $g$ dan terendah terdapat pada sampel $a$. Standar JIS A 59082003 mensyaratkan nilai MOE papan partikel minimal $20.400 \mathrm{~kg} / \mathrm{cm}^{2}$, maka papan partikel yang memenuhi standar dalam penelitian ini adalah sampel $e, f$, dan $g$. Nilai MOE papan partikel dapat dilihat pada Gambar 6.

Hasil penelitian menunjukkan bahwa penambahan batang kayu jabon berpengaruh terhadap peningkatan nilai keteguhan lentur. Komposisi bahan baku menggunakan kayu lebih baik dibandingkan papan partikel menggunakan seluruhnya non kayu. Nilai MOE yang semakin membaik karena pada saat partikel kayu jabon semakin ditambahkan, rongga yang terbentuk pada papan partikel akan semakin terisi. Hal ini menyebabkan jumlah partikel penyusun papan partikel menjadi semakin padat dan rongga menjadi semakin berkurang. Sehingga, nilai MOE akan semakin baik saat dilakukan penambahan partikel batang kayu jabon.

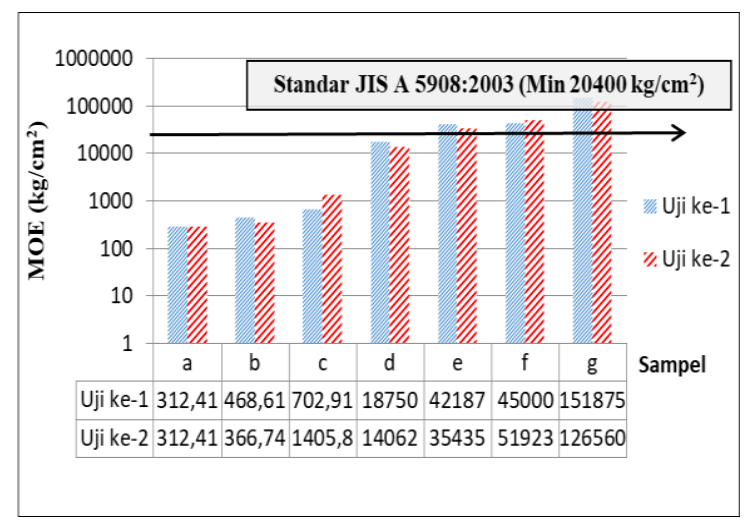

Gambar 6 Nilai MOE papan partikel pada setiap sampel untuk uji pertama dan uji kedua.

\section{b. MOR}

Modulus of Rupture (MOR) atau keteguhan patah merupakan kemampuan papan untuk menahan beban hingga batas maksimum. Hasil pengujian keteguhan patah papan partikel dapat dilihat pada Gambar 7.

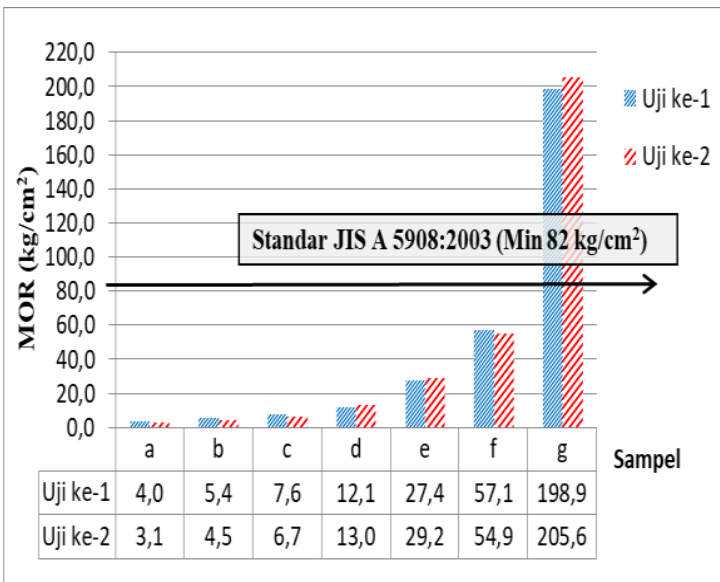

Gambar 7 Nilai MOR papan partikel pada setiap sampel untuk uji pertama dan uji kedua.

Nilai MOR tertinggi terdapat pada sampel $g$ dengan nilai $205,6 \mathrm{~kg} / \mathrm{cm}^{2}$, sedangkan nilai MOR terendah terdapat pada sampel $a$ yaitu 3,1 $\mathrm{kg} / \mathrm{cm}^{2}$. Standar JIS A 5908:2003 mensyaratkan nilai keteguhan lentur (MOR) papan partikel minimal $82 \mathrm{~kg} / \mathrm{cm}^{2}$ dan hanya satu yang memenuhi standar JIS yaitu sampel $g$.

Penambahan partikel batang kayu jabon yang semakin banyak, mengakibatkan nilai MOR 
yang dihasilkan semakin tinggi. Sehingga kualitas papan partikel semakin baik. Hal ini karena batang kayu jabon memiliki karakteristik yang kuat dan memiliki ketahanan yang cukup baik, sehingga dapat mempengaruhi nilai keteguhan lentur. Hasil yang diperoleh juga bersesuaian dengan nilai MOE yang sebelumnya telah diperoleh. Semakin tinggi nilai MOE maka nilai MOR juga akan mengalami peningkatan. Penyebabnya diduga seperti pada penjelasan MOE mengenai jumlah partikel penyusun papan partikel yang semakin padat dan rongga menjadi semakin berkurang saat penguat ditambahkan.

\section{c. Keteguhan Rekat Internal}

Keteguhan Rekat Internal (Internal Bond) ialah keteguhan tarik tegak lurus permukaan papan partikel. Internal Bond (IB) merupakan salah satu sifat mekanis yang menunjukkan besarnya nilai daya rekat antar partikel yang menyusun sebuah lembaran papan partikel. Hasil pengujian keteguhan rekat internal (IB) papan partikel dapat dilihat pada Gambar 8.

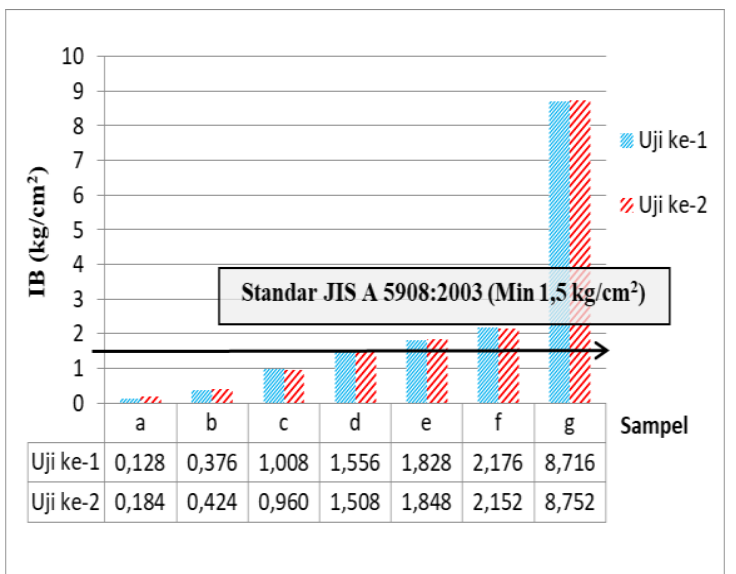

Gambar 8 Nilai keteguhan rekat internal papan partikel pada setiap sampel untuk uji pertama dan uji kedua.

Nilai yang ditetapkan pada keteguhan rekat internal minimal $1,5 \mathrm{~kg} / \mathrm{cm}^{2}$ (Standar JIS A 5908:2003), sehingga pada penelitian ini yang memenuhi standar adalah $d, e, f$, dan $g$. Papan partikel tertinggi terdapat pada sampel $g$ dan terendah pada sampel $a$ yaitu yang dibuat dari $100 \%$ kulit buah kakao.

Hasil penelitian menunjukkan semakin banyak penguat yang ditambahkan, maka semakin tinggi keteguhan rekatnya. Hal ini dikarenakan saat papan partikel dibuat tanpa penguat, banyak rongga yang terbentuk pada bagian dalam papan partikel. Rongga tersebut dapat memperlemah ikatan antar material penyusun papan partikel. Berbeda halnya dengan papan partikel yang dibuat dengan penguat, rongga yang semula terbentuk akan semakin terisi. Sehingga ikatan antar material penyusun di papan partikel menjadi lebih kuat. Ilustrasi papan partikel dengan rongga tinggi dan rendah disajikan pada Gambar 9.

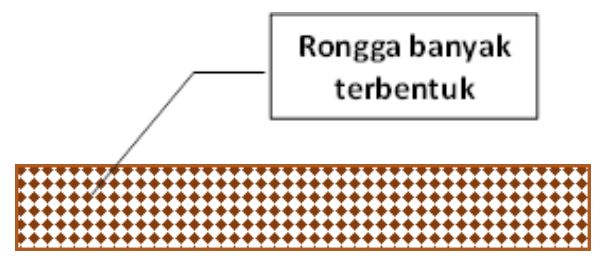

(a)

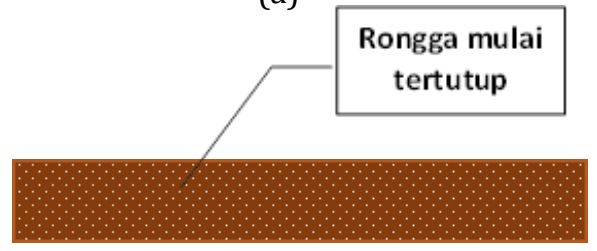

(b)

Gambar 9 Ilustrasi papan partikel dengan (a) rongga tinggi dan (b) rongga rendah.

Hal ini menunjukkan batang kayu jabon memiliki daya rekat internal yang baik daripada kulit buah kakao. Sehingga dengan adanya penambahan batang kayu jabon dapat mempengaruhi nilai IB menuju nilai yang lebih baik walaupun sampel $b$ dan $c$ tidak memenuhi standar yang telah ditetapkan.

\section{d. Kuat Pegang Sekrup}

Kuat pegang sekrup merupakan kemampuan papan partikel untuk menahan sekrup yang ditanamkan pada papan partikel. Hasil pengujian kuat pegang sekrup papan partikel dapat dilihat pada gambar 10 .

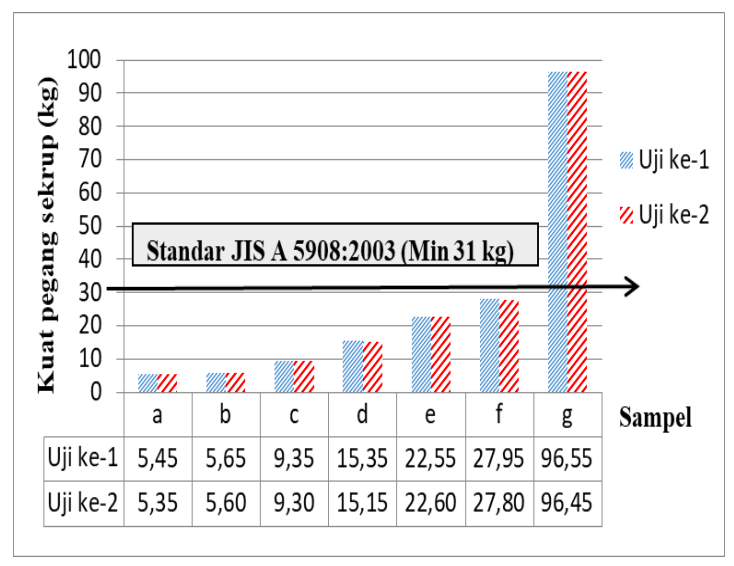

Gambar 10 Nilai kuat pegang sekrup papan partikel pada setiap sampel untuk uji pertama dan uji kedua.

Sampel yang memenuhi standar JIS adalah sampel $g$ dengan nilai kuat pegang sekrup tertinggi yaitu 96,55 kg. Untuk nilai terendah sebesar $5,35 \mathrm{~kg}$ pada sampel $a$. Nilai 
yang dihasilkan menuju nilai yang lebih baik walaupun sampel $b, c, d, e$, dan $f$ belum memenuhi standar yang telah ditetapkan. Hal ini terjadi karena adanya penambahan batang kayu jabon yang semakin banyak.

Faktor penyebab nilai kuat pegang sekrup diantaranya adalah keteguhan rekat internal (IB). Semakin tinggi nilai IB maka nilai kuat pegang sekrupnya juga akan semakin meningkat. Ikatan antar material penyusun akan semakin kuat saat partikel batang kayu jabon ditambahkan. Mengingat bahwa papan partikel yang dibuat tanpa penguat akan menghasilkan rongga dengan jumlah yang banyak. Setelah adanya penguat, rongga akan semakin terisi sehingga menyebabkan ikatan antar material penyusun di dalam papan partikel menjadi lebih kuat. Sehingga nilai kuat pegang sekrupnya pun akan meningkat seiring dengan penambahan penguat.

\section{Kesimpulan}

Berdasarkan hasil penelitian yang telah dilakukan, dapat disimpulkan bahwa partikel batang kayu jabon dan kulit buah kakao dapat dijadikan papan partikel dengan perekat urea formaldehyde (UF). Kerapatan pada papan partikel limbah kulit buah kakao, batang kayu jabon, maupun variasi campuran keduanya memenuhi standar yang telah ditetapkan. Kadar air dan pengembangan tebal nilainya belum memenuhi standar, kecuali pada $100 \%$ batang kayu jabon. Pengujian mekanis berupa MOE, MOR, IB, dan kuat pegang sekrup nilai yang dihasilkan semakin menuju ke kualitas yang semakin baik setelah adanya penambahan batang kayu jabon.

\section{Daftar Pustaka}

[1] Dianrifiya, N. dan Widya, D.R.P., Pemanfaatan Selulosa dari Kulit Buah Kakao (Teobroma cacao L.) sebagai Bahan Baku Pembuatan CMC (Carboxymethyl Cellulose), Jurnal Pangandan Agroindustri., 2(3), 34-42, 2014.

[2] Figuiera, A.; Janick, J.; and Be Miller, J.N., New Product from Theobroma cacao: Seed pulpand pod gum, P.475-476, In Janick J and J.E. Simon (eds), New Crops, Wiley, New York, 1993.

[3] Direktorat Jenderal Perkebunan, Statistik Perkebunan Kakao Indonesia, Jakarta, 2017.

[4] Ashadi, R.W., Pembutaan Gula Cair dari Pod Coklat dengan Menggunakan Asam Sulfat, Enzim, serta Kombinasi Keduanya. Institut Pertanian Bogor, Fakultas
Teknologi Pertanian, Bogor, (Skripsi), 1988.

[5] Cahyono, T.D.; Ohorella, S.; Febrianto, F., Sifat Fisis dan Mekanis Kayu Samama (Antocephalus macrophylus roxb) dari Kepulauan Maluku, Jurnal IImu dan Teknologi Kayu Tropis., 10(1), 2012.

[6] Khaerudini, D.S.; dan Muljadi., Pengaruh Variasi Sludge-Serbuk Kayu sebagai Penguat Terhadap Sifat Mekanik Material Komposit Matriks Urea Formaldehide, Jurnal Fisika dan Aplikasinya., 3(1), 1-5, 2007.

[7] Aminah, Sifat Fisik dan Mekanik Papan Partikel dari Limbah Kayu Acacia crassicarpa pada Beberapa Ukuran Partikel dan Konsentrasi Urea Formaldehida, Universitas Tanjungpura, Fakultas Kehutanan, Pontianak, (Skripsi), 2018.

[8] Erwan, Sintesis Analisis Sifat Fisik dan Mekanik Papan Komposit dari Limbah Pelepah Sawit dan Sabut Kelapa, Universitas Tanjungpura, Fakultas Matematika dan Ilmu Pengetahuan Alam, Pontianak, (Skripsi), 2015.

[9] [JSA] Japanese Standard Association, Japanesse Industrial Standard Particle Board JIS A 5908, Tokyo: Japanese Standard Association, 2003.

[10] Pratiwi, Prospek Pohon Jabon untuk Pengembangan Hutan Tanaman, Buletin Penelitian dan Pengembangan Kehutanan., 4(1), 61-66, 2003.

[11] Ruhendi, S.; dan Putra, E., Sifat Fisis dan Mekanis Papan Partikel dari Batang dan Cabang Kayu Jabon (Anthocephalus cadamba Miq), Ilmu dan Teknologi Hasil Hutan., 4(1), 14-21, 2011.

[12] Haygreen, J.G.; dan Bowyer, J.L.; Shmulsky, R., Forest Product and Wood Science, An Introduction Fourth Edition, United state of America: Low a State Press, 2003. 